\title{
Karakteristik Sosis Ikan Nila (Oreochromis niloticus) dengan Penambahan Tepung Rumput Laut (Gracilaria sp)
}

\author{
[Characteristics of Tilapia Sausage (Oreochromis niloticus) with \\ Addition of Seaweed Flour (Gracilaria sp)] \\ Yuliati H. Sipahutar, Ahadin F F Ma'roef, Asri A Febrianti, Cakra Nur, \\ Noviatun Savitri, Selvya P Utami, \\ Politeknik Ahli Usaha Perikanan Jakarta \\ JI. Aup Barat Jl. Raya Pasar Minggu, RT.1/RW.9 • (021) 7806874
}

\begin{abstract}
Abstrak
Penelitian ini bertujuan untuk mengetahui penggunaan tepung rumput Gracilaria $s p$ terhadap karakteristik sosis ikan nila. Rumput laut Gracilaria sp diperoleh langsung dari budidaya rumput laut di perairan Kabupaten Karawang. Penelitian ini menggunakan metode eksperimen, dengan perlakuan penambahan tepung rumput laut Gracilaria $s p$ $0 \% ; 3 \% ; 6 \%, 9 \%$ dan $12 \%$, dengan tiga kali ulangan. Parameter uji yaitu uji sensori, uji kimia (kadar air, abu, lemak, protein dan serat pangan) dan uji mikrobilogi ALT, Salmonella dan Escherichia coli. Analisis data menggunakan analisis rata-rata, dilakukan secara deskriptif. Hasil penelitian parameter hedonik, menunjukkan perlakuan terbaik pada sosis ikan nila adalah penambahan tepung rumput laut Gracilaria $s p$ sebesar $3 \%$, dengan nilai kenampakan 8,1 ; bau 7,6 ; rasa 7,8;tekstur 7,5 . Uji kimia kadar protein 2,21\%, lemak 2,8\%, kadar abu 1,76\%, kadar air 58,77\%. Uji mikrobilogi ALT 3,4 X $10^{2} \mathrm{kol} / \mathrm{gr}$, Escherichia coli negatif dan Salmonella negatif Penambahan tepung rumput laut Gracilaria sp. sebagai bahan tambahan sosis ikan akan meningkatkan tekstur sosis ikan nila.
\end{abstract}

Kata Kunci : Bahan tambahan, Gracilaria sp, ikan nila, sosis

\section{Abstract}

This research was aimed to observe the effect of using from Gracilaria sp powder on the characteristics of tilapia fish sausages. Gracilaria $s p$ seaweed is ob tained directly from seaweed cultivation in the waters of Karawang Regency. Five different concentrations of Gracilaria sp powder $(0 \%, 3 \%, 6 \%, 9 \%, 12 \%)$ were used with three replications. The quality of the sausage was decided based on the sensory and the chemical test The test parameters are sensory test, chemical test (water content, ash content, fat content, protein content and food fiber content) and microbial test of ALT, Salmonella and Escherichia coli. Testing data using average analysis, done descriptively. The results showed that the addition of Gracilaria sp powder the best treatment parameters for tilapia fish sausage of Gracilaria sp seaweed flour by $3 \%$, with an appearance value of 8.1 , smell of 7.6 , taste of 7.8 , texture of $7.5,2.21 \%$ protein content, $2.8 \%$ fat, $1.76 \%$ ash content, $58.77 \%$ water content. The TPC microbilogy test $3.4 \times 10^{2} \mathrm{col} / \mathrm{g}$, Escherichia coli negative and Salmonella negative. The addition of Gracilaria $s p$ powder as a an additional ingredient will improve the texture of tilapia fish sausage.

Key Words : food additive, gracilaria sp, sausage, tilapia sausage

\section{Penulis Korespondensi}

Yuliati H. Sipahutar | yuliati.sipahutar@gmail.com 


\section{PENDAHULUAN}

Rumput laut Gracilaria sp. umumnya mengandung agar atau disebut juga agar-agar sebagai hasil metabolisme primernya. Agar-agar diperoleh dengan melakukan ekstraksi rumput laut pada suasana asam setelah diberi perlakuan basa serta diproduksi dan dipasarkan dalam berbagai bentuk, yaitu: agaragar tepung, agar-agar kertas dan agar-agar batangan serta diolah menjadi bahan tambahan industri farmasi. Komponen utama rumput laut menurut Chapman dan Chapman (1980) adalah karbohidrat (polisakarida) dan protein yang serupa dengan gandum. Komposisi rumput laut Gracilaria sp dalam 100 g kering) adalah : Kalori (kkal) 312; Protein (g) 1,3; lemak (g) 1,3; Karbohidrat (g) 83,5; serat (g); abu (g) 4, (Suhartono, 2000)

Sosis merupakan salah satu produk diversifikasi perikanan. Sosis adalah daging lumat yang dicampur dengan bumbu dan rempah-rempah kemudian dimasukkan serta dibentuk dalam pembungkus atau casing (Kementerian Pendidikan dan Kebudayaan Republik Indonesia, 2013) Tekstur sosis yang kenyal banyak disukai oleh semua kalangan, baik anak-anak maupun dewasa. Sosis yang terdapat di pasaran umumnya terbuat dari daging sapi dan ayam yang memiliki kandungan lemak relatif tinggi, dan masih jarang ditemukan sosis yang terbuat dari daging ikan. Pada prinsipnya hampir semua jenis ikan dapat dimanfaatkan untuk membuat sosis, seperti ikan tuna, ikan lemuru, ikan tongkol, ikan remang, ikan tenggiri dan ikan-ikan lainnya (Pusat Pendidikan Kelautan dan Perikanan, 2015)

Penelitian ini bertujuan untuk memanfaatkan tepung Gracilaria sp yang digunakan sebagai pembentuk gel pada bakso ikan nila, dan mendapatkan produk terpilih bakso ikan nila dengan penambahan konsentrasi rumput laut $0 \%, 3 \%, 6 \%$, $8 \%$, dan $12 \%$. Manfaat penelitian ini memberikan informasi kepada masyarakat tentang Gracilaria sp. sebagai bahan tambahan makanan yang aman untuk menggantikan boraks sebagai pengeyal yang dapat membahayakan kesehatan.

\section{BAHAN DAN ALAT}

Penelitian dilakukan bulan Mei sampai dengan Juli 2019, bertempat di Workshop Pengolahan, Laboratorium Kimia, dan Laboratorium Mikrobiologi Politeknik Ahli Usaha Perikanan Jakarta.

\section{Alat dan Bahan}

Alat yang yang digunakan dalam pembuatan sosis ikan nila 
adalah pisau, talenan, silent cutter, saringan, baskom, mesin pencetak sosis, mesin perebusan, oven, timbangan digital, nampan, sealer, food processor. Alat yang digunakan untuk membuat tepung agar yaitu hot plate, beaker glass, spatula, erlenmeyer, timbangan digital, pan penjendal, kain belacu, dan mesin penepung. Alat yang digunakan untuk pengujian mikrobiologi adalah gelas ukur, timbangan, erlenmeyer, pipet, autoclave, inkubator $35^{\circ} \mathrm{C}$, kantong plastik tahan panas, kapas, kertas kopi, karet gelang, sendok, gunting dan pinset sampel, gunting stainless steel, cawan petri, botol sample, bunsen, alkohol, stomacher, botol pengencer, rak dan tabung reaksi, tabung durham, dan micro pipette.

Bahan utama yang digunakan dalam pengolahan sosis ikan ini adalah tepung agar dari rumput laut Gracilaria sp. dan bahan surimi ikan nila. Bahan pembantu tepung tapioka sebagai binder, Isolate Soy Protein (tepung kedelai), telur, bumbu-bumbu rempah seperti garam halus, gula halus, merica, bawang putih, air, dan es. Bahan selulos sosis yang terbuat dari plastik, benang halus untuk mengikat sosis. Bahan kimia yang digunakan untuk membuat tepung agar adalah $\mathrm{NaOH}, \mathrm{HCl}$, kaporit dan asam asetat. Bahan yang digunakan untuk pengujian mikrobiologi adalah
Plate Count Agar (PCA), Bakto Pepton, aquades, $\mathrm{NaCl} 85 \%$, alkohol 70\%, Lauryl Tryptose Broth (LTB), Brillian Green Lactose Broth (BGLB), EC Broth, dan larutan butterfields Phospate Buffered. Bahan yang digunakan untuk pengujian kimia adalah aquades, $\mathrm{H}_{2} \mathrm{SO}_{4}, \mathrm{NaOH}$, $\mathrm{K}_{2} \mathrm{SO}_{4}, \mathrm{CuSO} 4, \mathrm{H}_{3} \mathrm{BO}_{3}, \mathrm{HCl}$, indikator metil merah, indikator BCG, n-heksan.

\section{Metode Kerja}

Penelitian ini dilakukan dengan eksperimen dengan perlakuan penambahan tepung rumput laut Gracilaria sp. dengan 5 konsentrasi yaitu $0 \%, 3 \%, 6 \%, 9 \%$, dan $12 \%$ dengan 3 kali ulangan. Proses pembuatan sosis ikan mengacu pada SNI 7755-2013 tentang sosis ikan dengan sedikit modifikasi (BSN, 2013).

Metode penelitian meliputi rancangan percobaan, persiapan, pembuatan sampel sosis ikan nila. Metode eksperimen menggunakan rancangan acak lengkap dengan tiga kali ulangan. Analisis data menggunakan analisis non parametrik yaitu pengujian organoleptik dengan skala mutu hedonik Analisis dilakukan secara deskriptif dan melihat nilai rata-rata hedonik.

Metode uji hedonik adalah mengukur tingkat preferensi untuk suatu produk menggunakan lembar 
penilaian. Skala hedonik berkisar 1 -

9. Sosis ikan dinilai oleh 30 panelis semi terlatih yang dipilih secara acak, yang sudah mengenal sosis ikan (BSN, 2006). Sosis ikan nila dengan penambahan tepung Gracilaria sp diuji hedonik untuk menentukan produk terpilih. Setelah didapatkan produk terpilih, dilakukan uji mutu kimia dan mikrobiologi.

Uji kimia dilakukan dengan parameter kadar air sesuai SNI 2354.2:2015 (BSN, 2015), kadar abu SNI 2354.1: 2010 (BSN 2010), kadar protein SNI 01-2354.4-2006 (BSN, 2006). Kadar lemak SNI01-2354.32006 (BSN, 2006)

Uji mikro dilakukan dengan parameter ALT sesuai dengan SNI 01-2332.3-2006 (BSN, 2006b), Escherichia coli SNI 01-2332.12006 (BSN 2006a). Salmonella SNI 01-2332.2-2006 (BSN, 2006b)

\section{Rancangan}

percobaan

penelitian ini dengan 5 perlakuan konsentrasi dapat dilihat pada komposisi adonan bakso ikan per unit percobaan pada Tabel 1:

Tabel 1. Komposisi sosis ikan nila per unit percobaan

\begin{tabular}{llll}
\hline \multicolumn{1}{c}{ Bahan-bahan } & \multicolumn{1}{c}{ Berat } & Satuan \\
\hline Surimi & 500 & $\mathrm{~g}$ \\
Tepung Tapioka & 100 & $\mathrm{~g}$ \\
Tepung Kedelai & 150 & $\mathrm{~g}$ \\
Telur & 1 & Butir \\
Bawang Putih & 15 & $\mathrm{~g}$ \\
Gula & 15 & $\mathrm{~g}$ \\
Garam & 15 & $\mathrm{~g}$ \\
Minyak Sayur & 25 & $\mathrm{~g}$ \\
Merica & 5 & $\mathrm{~g}$ \\
Tepung gracilaria & $0 ; 3,6 ; 9 ; 12$ & $\%$ \\
\hline rangan : Penambahan Tepung Gracilaria sp berdasarkan berat daging ikan
\end{tabular}

\section{HASIL DAN PEMBAHASAN}

\section{Hasil}

Pengujian mutu sosis dengan perlakuan penambahan tepung Gracilaria sp dengan konsentrasi yang berbeda dilakukan dengan uji sensori, uji kimia dan uji mikrobiologi.

\section{Pengujian Sensori}

Salah satu metode penilaian mutu produk sosis ikan yaitu dengan penilaian subjektif, disebut juga penilaian sensori. Uji sensori dilakukan dengan panca indera 
pengamat untuk menilai faktor-faktor mutu yang umumnya dikelompokkan atas penampakan, bau, cita rasa, dan tekstur (BSN, 2006). Sifat organoleptik yang berhubungan dengan sifat fisik, sangat memegang peranan penting terutama untuk menentukan komoditas yang masih segar atau sudah busuk (Fajriyanti, 2013)

Pengujian sensori dilakukan untuk mengetahui kesukaan konsumen pada sosis ikan nila sebagai berikut:

Tabel 2. Hasil Pengujian Sensori

\begin{tabular}{|c|c|c|c|c|c|}
\hline $\begin{array}{l}\text { Spesifik } \\
\text { asi }\end{array}$ & $0 \%$ & $\begin{array}{l}3 \\
\%\end{array}$ & $6 \%$ & $9 \%$ & $\begin{array}{l}12 \\
\%\end{array}$ \\
\hline $\begin{array}{l}\text { Kenamp } \\
\text { akan }\end{array}$ & 8,1 & $\begin{array}{l}8 \\
1\end{array}$ & 7,2 & 7,9 & 7 \\
\hline Bau & 7,2 & $\begin{array}{l}7 \\
6\end{array}$ & $\begin{array}{l}6,5 \\
3\end{array}$ & 6,9 & 6,6 \\
\hline Rasa & 7,3 & $\begin{array}{l}7 \\
8\end{array}$ & 7 & 7,3 & 6,6 \\
\hline Tekstur & 7,3 & $\begin{array}{l}7 \\
5\end{array}$ & $\begin{array}{l}7,1 \\
7\end{array}$ & 7,4 & 6,3 \\
\hline$\sum_{\text {Jumlah }}$ & $\begin{array}{l}7,4 \\
75\end{array}$ & $\begin{array}{l}7 \\
75\end{array}$ & $\begin{array}{l}6,9 \\
75\end{array}$ & $\begin{array}{l}7,3 \\
73\end{array}$ & $\begin{array}{l}6,6 \\
25\end{array}$ \\
\hline
\end{tabular}

Pengujian kimia produk terpilih

Produk sosis ikan nila yang terpilih adalah dengan penambahan bahan tambahan tepung Gracilaria $s p$ dengan konsentrasi $3 \%$, selanjutnya diuji kimia untuk mengetahui mutunya.
Pengujian sosis ikan dilakukan dengan acuan pada SNI 7765:2013 sebagai berikut:

Tabel 2. Hasil Pengujian kimia sosis terpilih $3 \%$

\begin{tabular}{lrl}
\hline \multicolumn{1}{c}{ Pengujian } & \multicolumn{1}{c}{ Nilai } & \multicolumn{1}{c}{ SNI } \\
\hline Kadar Air $\%$ & $58,77 \%$ & Maks 68,0 \\
Kadar Abu \% & $1,76 \%$ & Maks 2,5 \\
$\begin{array}{l}\text { Kadar Protein } \\
\%\end{array}$ & $2,21 \%$ & Min 9,0 \\
$\begin{array}{l}\text { Kadar Lemak } \\
\%\end{array}$ & $2,8 \%$ & Maks 7,0 \\
\hline
\end{tabular}

Pengujian Mikrobiologi produk terpilih

Produk sosis ikan nila yang terpilih diuji mikrobiologi sesuai dengan dengan acuan pada SNI 7765:2013 sebagai berikut :

Tabel 3. Hasil Pengujian mikrobilogi sosis terpilih $3 \%$

\begin{tabular}{lll}
\hline \multicolumn{1}{c}{ Pengujian } & \multicolumn{1}{c}{ Nilai } & \multicolumn{1}{c}{ SNI } \\
\hline ALT kol/g & $3,4 \times 10^{2}$ & $\begin{array}{l}\text { Maks } \\
\end{array}$ \\
& & $5 \times 10^{4}$ \\
E. coli dan & Negatif/25 & $<3$ \\
coliform & $\mathrm{g}$ & APM/25g \\
Salmonela & Negatif/25 & Negatif/ 25 \\
& $\mathrm{g}$ & $\mathrm{g}$ \\
\hline
\end{tabular}

Pembahasan

Uji Sensori

1) Kenampakan

Kenampakan merupakan faktor utama dalam penilaian panelis terhadap suatu produk. (Soekarto 2008). Kenampakan adalah unsur penilaian awal seorang konsumen terhadap suatu produk pangan yang disajikan (Hasibuan, 2017) . Hal ini disebabkan karena jika kesan 
Karakteristik Sosis Ikan Nila (Oreochromis niloticus)

dengan Penambahan Tepung Rumput Laut (Gracilaria sp)

kenampakan baik dan disukai, maka

meskipun kenampakan tidak

panelis akan melihat parameter yang menentukan tingkat kesukaan lainnya (aroma, bau, dan rasa). konsumen secara mutlak (Sipahutar, Kenampakan juga memengaruhi et al, 2020)

penerimaan konsumen,

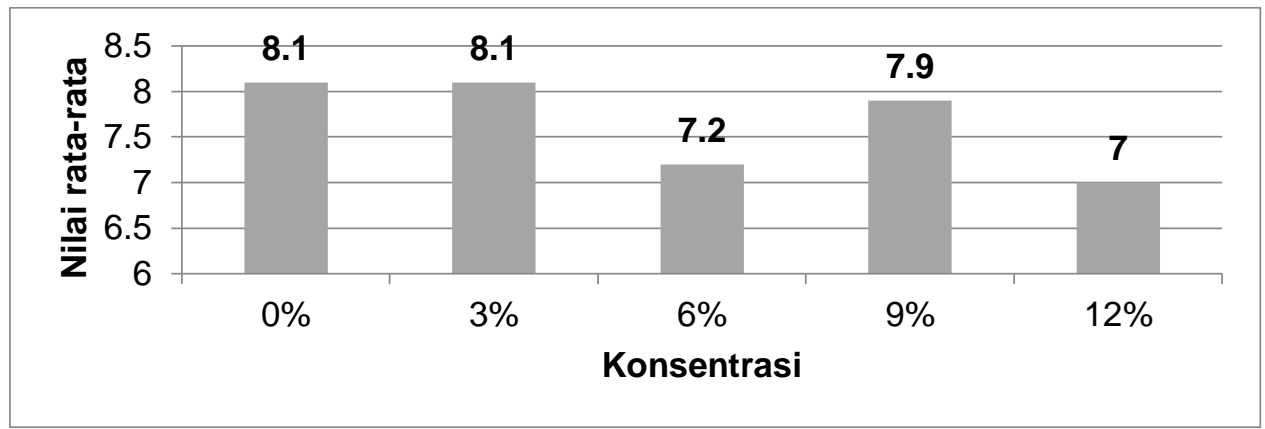

Gambar 1. Nilai rata-rata kenampakan

Berdasarkan hasil pengamatan terhadap kenampakan sosis ikan nila didapatkan nilai tertinggi dari panelis yaitu 8,1 dengan spesifikasi sangat suka pada penambahan tepung Gracilaria sp. 0\% dan 3\%, dan nilai terendah yaitu 7 dengan spesifikasi suka pada penambahan tepung Gracilaria sp. 12\%. Sifat hidrokoloid bubuk Gracilaria $s p$. mampu menyerap air, sehingga tampilan sosis akan terlihat kering dan kompak. Evaluasi penampilan sosis secara umum mencakup semua kriteria yang diuji oleh organoleptik yang meliputi bentuk bulat, kebersihan, kerapian, kerataan warna, dan kecemerlangan. Menurut Yaska et al, (2017) perlakuan rasio tapioka dengan rumput laut Gracilaria $s p$. berpengaruh pada uji hedonik warna, rasa, tekstur. Rasio ikan dan tepung berpengaruh terhadap daya kembang produk, dimana peningkatan kandungan protein ikan dalam adonan akan menurunkan daya kembang. Penelitian Sipahutar, et al, (2020) menunjukkan bahwa tepung Gracilaria sp. semakin banyak berpengaruh terhadap perubahan kenampakan sosis ikan dengan warna sosis yang semakin gelap. Kenampakan adalah unsur penilaian awal seorang konsumen terhadap suatu produk pangan yang disajikan. Kenampakan biasanya disebut juga kesan pertama yang timbul setelah panelis melihat sosis yang dipengaruhi oleh unsur warna dan bentuk dari produk itu sendiri.

2) $\mathrm{Bau}$

Bau adalah zat kimia yang tercampur di udara, umumnya 
dengan konsentrasi yang sangat dengan indra penciuman (De Man, rendah, yang manusia terima 2010)

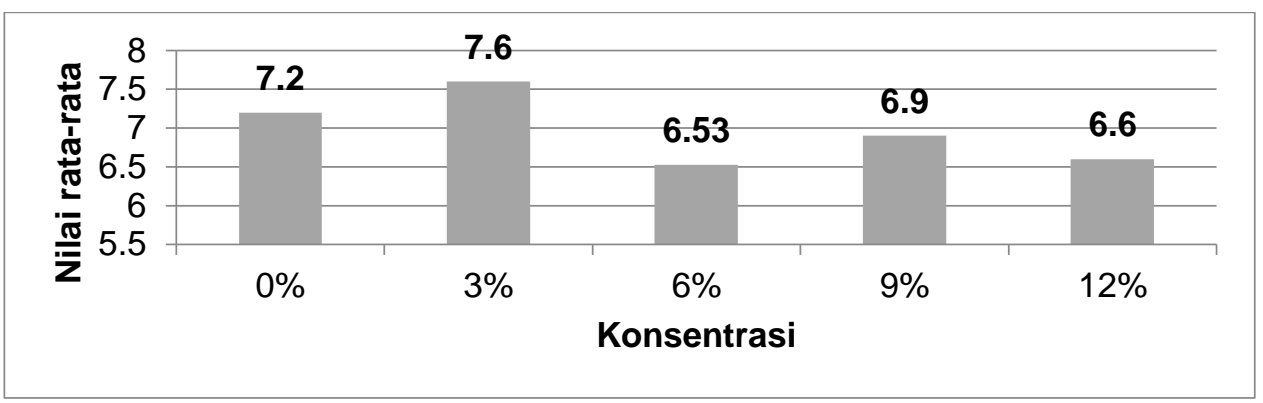

Gambar 2. Nilai rata-rata bau

Berdasarkan hasil pengamatan terhadap bau sosis ikan nila didapatkan nilai tertinggi dari panelis yaitu 7,6 dengan spesifikasi sangat suka pada penambahan tepung Gracilaria 3\% dan nilai terendah yaitu 6,53 dengan spesifikasi suka pada penambahan tepung Gracilaria $6 \%$ Penilaian suatu makanan terhadap uji bau dianggap penting karena dengan cepat memberikan penilaian terhadap suatu produk. Salah satu faktor yang menentukan suatu makanan dapat diterima oleh konsumen adalah aroma (bau). Aroma (bau) makanan banyak menentukan kelezatan makanan tersebut. Pada umumnya bau yang diterima oleh hidung dan otak merupakan ramuan atau campuran empat bau utama yaitu harum, asam, tengik, dan hangus (Winarno, 2014) Penelitian Princestasari dan Amalia (2015) tentang penambahan Gracilaria sp pada bakso menunjukkan nilai hedonik bau tidak berpengaruh nyata terhadap atribut bau. Hal ini karena bau rumput laut yang berbau amis spesifik, setelah dilakukan proses pencucian dan perendaman dengan baik, menghasilkan rumput laut menjadi tidak berbau amis. Sebagian besar aroma produk makanan datang dari bahan baku yang digunakan dan rempah-rempah yang ditambahkan.

3) Rasa

Faktor rasa memegang peranan penting dalam pemilihan produk oleh konsumen. Adanya penambahan bahan-bahan tertentu pada suatu produk dapat mempengaruhi rasa (Winarno, 2014). Rasa yang kurang enak, walaupun kandungan gizinya baik, tidak dapat diterima oleh konsumen maka target meningkatkan gizi masyarakat tidak dapat tercapai dan produk tidak laku. 


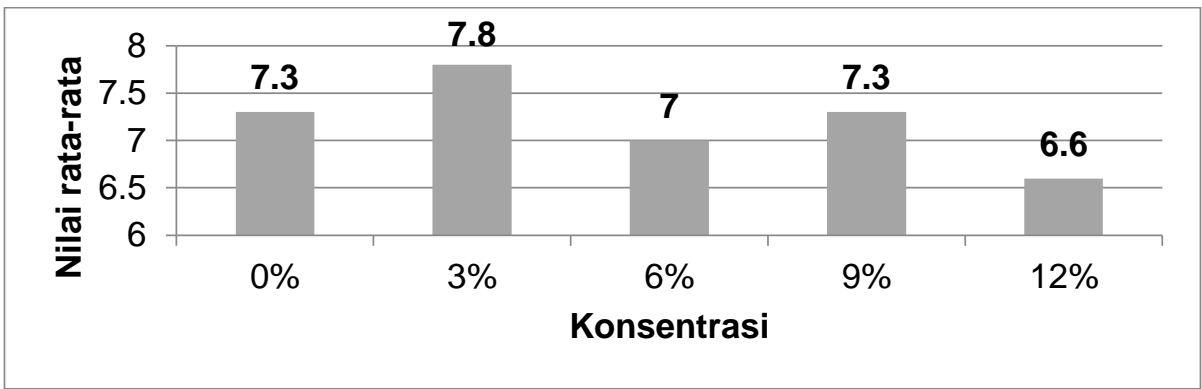

Gambar 3. Nilai Rata-Rata Rasa

Berdasarkan hasil pengamatan terhadap rasa sosis ikan nila maka didapatkan nilai tertinggi dari panelis yaitu 7,8 dengan spesifikasi sangat suka pada penambahan tepung gracilaria $3 \%$ dan nilai terendah yaitu 6,6 dengan spesifikasi suka pada penambahan tepung Gracilaria 12\%. Hasil penelitian Sulistyaningrum dan Elita (2015) pada sosis ikan lele dumbo didapatkan nilai tertinggi dari panelis yaitu 7 dengan spesifikasi sangat suka dan nilai terendah yaitu 6 dengan spesifikasi suka. Nilai rasa dipengaruhi oleh selera panelis terhadap sosis ikan nila. Dari nilai rata-ratanya dapat dilihat bahwa panelis sangat menyukai sosis ikan nila. Rasa merupakan faktor kedua yang mempengaruhi cita rasa makanan setelah penampilan makanan

4) Tekstur

Penilaian tekstur bertujuan untuk mengetahui penerimaan panelis terhadap tingkat elastisitas atau kekenyalan suatu produk yang dapat dinilai menggunakan indera peraba, yaitu lewat rangsang sentuhan (De Man, 2010)

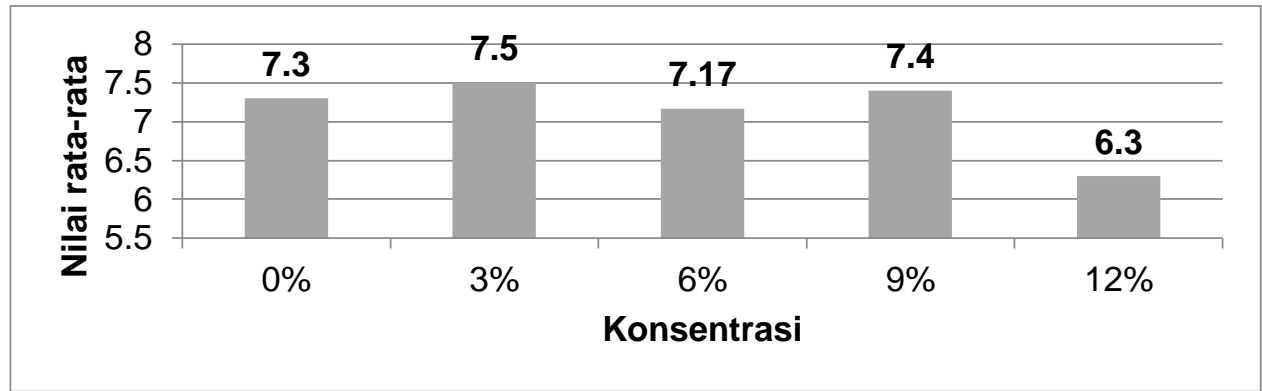

Gambar 4. Nilai Rata-Rata Tekstur

Berdasarkan hasil pengamatan terhadap tekstur ikan nila maka didapatkan nilai tertinggi dari panelis yaitu 7,5 dengan spesifikasi sangat suka pada penambahan tepung
Gracilaria sp 3\% dan nilai terendah yaitu 6,3 dengan sepesifikasi suka pada penambahan tepung Gracilaria sp $12 \%$. Hal ini dapat dilihat bahwa nilai tekstur yang disukai adalah kenyal dan tidak terlalu keras dan 
tidak juga lembek. Penelitian Sipahutar et al, (2020) tentang penambahan tepung Gracilaria $s p$ pada sosis ikan memberikan pengaruh terhadap kekenyalan tekstur sosis. Penelitian (Wiraswanti et al, 2008) menunjukkan bertambah tingginya konsentrasi tepung Gracilaria sp yang ditambahkan, akan menurunkan nilai hedonik tekstur. Hal ini diduga penambahan tepung Gracilaria sp yang terlalu banyak dapat mengikat molekul air terlalu banyak sehingga menjadi basah menyebabkan tekstur yang dihasilkan cenderung menjadi semakin lembek. Penelitian Yakhin et al, (2013) tentang sosis ikan dengan tepung tapioka sebagai bahan pengisi dan tepung rumput laut Gracilaria $s p$ sebagai gelling agent dapat meningkatkan kualitas gel sosis ikan, karena kandungan hidrokoloid agar yang dikandungnya.

Tekstur adalah salah satu sifat bahan atau produk yang dapat dirasakan melalui sentuhan kulit atau pencicipan. Beberapa sifat tekstur yaitu, kekenyalan, kekerasan, dan kelembekan produk.

\section{Pengujian kimia produk terpilih}

Produk sosis ikan nila yang terpilih adalah penambahan bahan tambahan tepung Gracilaria $s p$ dengan konsentrasi $3 \%$, selanjutnya diuji kimia dan mikro untuk mengetahui mutunya.
1) Kadar Air

Pada Tabel 2 diatas menunjukkan bahwa uji kadar air sosis adalah $58,77 \%$. Berdasarkan SNI 7755:2013, nilai kadar air sosis maksimal yaitu sebesar $68,0 \%$ sehingga kadar air yang dihasilkan masih memenuhi persyaratan mutu dan keamanan pangan.

Penelitian Sipahutar, et al, (2020) didapatkan kadar air sosis ikan kurisi berkisar antara $60.66 \%$ $61.75 \%$. Hal ini di dukung hasil penelitian Sulistyaningrum (2018) dimana hasil uji kimia untuk protein, air dan lemak sosis ikan lele dumbo yang terbaik adalah pada penambahan rumput laut $2 \%$. Kadar air sosis menentukan daya awet bahan pangan tersebut, kadar air yang terlalu tinggi mengakibatkan mudahnya mikroorganisme untuk berkembang biak sehingga akan terjadi perubahan baik dari segi warna, aroma, rasa, dan tekstur. Hal ini sesuai dengan makin rendah kadar air, makin lambat pertumbuhan mikroorganisme berkembang biak, sehingga proses pembusukan akan berlangsung lebih lambat (Estiasih dan Ahmadi, 2016).

2) Kadar Abu

Pada Tabel 2. diatas menunjukkan bahwa uji kadar abu sosis adalah 1,76\%. Berdasarkan SNI 7755:2013, nilai kadar abu sosis 
maksimal yaitu sebesar $2,5 \%$ sehingga kadar abu yang dihasilkan memenuhi persyaratan mutu dan keamanan pangan. Menurut Sulistyaningrum (2018) hasil uji kimia untuk potein, kadar air dan lemak sosis ikan lele dumbo yang terbaik adalah pada penambahan rumput laut $2 \%$. Penambahan rumput laut pada kualitas kimia yaitu meningkatkan kadar air. Kandungan abu pada sosis ini berasal dari kandungan mineral yang terdapat pada ikan nila dan garam yang ditambahkan (Sipahutar, et al,, 2020). Selain itu, rendahnya kadar abu tersebut dapat disebabkan akibat pencucian yang terjadi. Pencucian mengakibatkan bahanbahan inorganik garam dan bahan organik molecular rendah menghilang.

\section{3) Protein}

Dari hasil yang didapatkan dalam penelitian ini kandungan protein sosis ikan nila adalah 2,21 \%. Berdasarkan SNI 7755:2013, nilai kadar protein sosis minimal yaitu sebesar $9,0 \%$ sehingga kadar protein yang dihasilkan masih kurang memenuhi persyaratan mutu dan keamanan pangan. Penelitian Sulistyaningrum dan Elita (2015) didapatkan kandungan protein sosis ikan lele dumbo dengan penambahan karagenan adalah
7,76\%. Semakin banyak lemak yang terlepas pada saat pemasakan maka stabilitas emulsi akan menurun dan akhirnya akan pecah (Astawan, 2004). Penambahan tepung karagenan memberikan pengaruh nyata terhadap peningkatan kekuatan gel bakso ikan gabus (Karim dan Aspari, 2015). Protein adalah sumber asam amino, baik esensial maupun nonesensial (Winarno, 2014). Hampir semua jenis protein mengandung asam amino yang mempunyai sifat larut dalam air serta mengumpul jika terkena panas (terjadi gelatinisasi).

4) Kadar Lemak

Pada Tabel 2. diatas menunjukkan bahwa uji kadar lemak sosis adalah 2,8\%. Berdasarkan SNI $7755: 2013$, nilai kadar lemak sosis maksimal yaitu sebesar 7,0\% sehingga kadar lemak yang dihasilkan memenuhi persyaratan mutu dan keamanan pangan. Penelitian (Yaska et al, 2017) menunjukkan perlakuan rasio tapioka dengan rumput laut Gracilaria sp berpengaruh sangat nyata pada sosis lemuru. . Penambahan rumput laut Gracilaria sp. pada sosis ikan lemuru dapat meningkatkan kestabilan emulsi pada sosis. Hal ini pada dasarnya sosis merupakan suatu produk olahan daging yang berbentuk 
emulsi lemak. Pada proses perebusan keluarnya lemak pada jaringan daging ikan selama perebusan dapat dicegah dengan stabilnya emulsi

\section{Pengujian mikrobiologi produk terpilih}

1). Angka Lempeng Total (ALT)

Pada Tabel 3. diatas menunjukkan bahwa ALT sosis adalah $3,4 \times 10^{2} \mathrm{kol} / \mathrm{g}$. Standar bahan baku adalah $3 \times 10^{3} \mathrm{kol} / \mathrm{g}$. Hal tersebut menunjukkan bahwa nilai ALT bakteri dari sosis lebih kecil dari nilai standar ALT yang berdasarkan SNI (BSN, 2015d), sehingga sosis tersebut masih layak atau bisa dikonsumsi. Sosis yang mengandung cemaran baik biologis yaitu cemaran mikroba ataupun cemaran kimia yang melampaui ambang batas maksimal yang telah ditetapkan adalah pangan tercemar. Sedangkan sosis yang diuji nilai ALT bakterinya kurang dari ambang batas maksimal sehingga dapat dikatakan bahwa sosis yang diuji memiliki kualitas yang baik.

\section{2). Escherichia coli}

Pada Tabel 3. diatas menunjukkan bahwa sosis negatif mengandung bakteri E. coli dan Coliform. Pengujian ini dilakukan dengan 2 tahap. Tahap pertama yaitu uji pendugaan dengan menggunakan media LTB (Lauryl
Tryptose Broth). Uji ini dilakukan untuk mengetahui ada atau tidaknya mikroorganisme pada sampel sosis dengan indikator ada atau tidaknya gelembung pada media dalam waktu 1x24 jam. Berdasarkan data yang diperoleh, terdapat 9 tabung reaksi yang tampak adanya gelembung. Dapat disimpulkan untuk uji pendugaan pada sampel ditemukan mikroba yang mampu memfermentasikan laktosa yang berarti mikroba tersebut menghasilkan gas pada tabung durham. Terbentuknya gelembung gas dalam tabung durham disebabkan karna adanya mikroba pembentuk gas (Fardiaz, 2008)

Tahap kedua yaitu uji penegasan menggunakan media BGLB ( Brilliant Green Lactose Broth) dan EC Broth. Setelah diinkubasi selama 48 jam, didapatkan data yang diperoleh bahwa dari 9 tabung menunjukkan hasil negatif. Ini berarti sampel sosis tidak terdapat mikroorganisme gram positif melainkan bakteri golongan kolon sehingga masih memenuhi persyaratan mutu dan keamanan pangan. Hal ini berarti bakteri E. coli mati setelah pemanasan pada suhu $70^{\circ} \mathrm{C}$ selama 3,5 detik. Ray dan Bhunia (2007) menyatakan bahwa mikroorganisme yang mengalami

perlakuan pemanasan pada suhu dan waktu pemanasan tertentu dapat 
mengalami heat-shock, sublethally

injured, atau kematian. Hasil uji E.

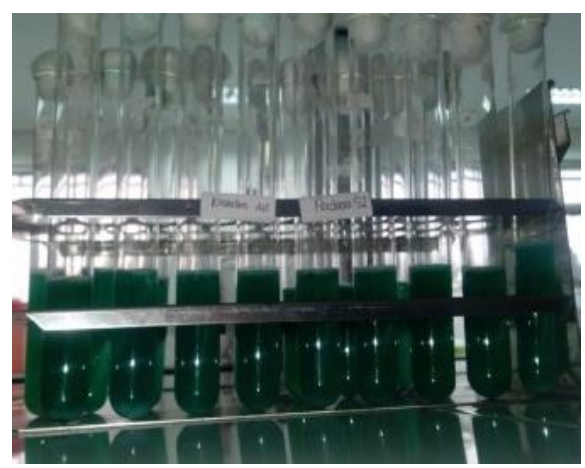

coli dan Coliform sosis dapat dilihat pada Gambar 5 berikut.

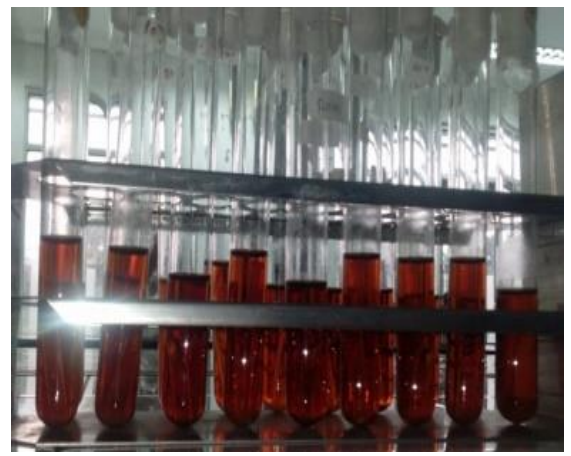

Gambar 5. Uji E. coli dan Coliform Sosis

7. Salmonella

Pada Tabel 3. diatas menunjukkan bahwa sosis negatif mengandung bakteri Salmonella. Dengan demikian, sampel sosis masih memenuhi persyaratan mutu dan keamanan pangan (BSN, 2015c). Hal ini didapatkan dalam pemanasan suhu tinggi, maka bakteri akan mati. Pengujian ini bertujuan untuk mengidentifikasi keberadaan bakteri Salmonella pada sampel sosis. Badan Kesehatan Dunia
(WHO) menyatakan Salmonella adalah genus bakteri yang merupakan penyebab utama penyakit bawaan makanan di seluruh dunia. Penyebab adanya bakteri Salmonella pada sampel sosis disebabkan oleh dua faktor yaitu faktor internal dan faktor eksternal yang dapat mengakibatkan diare atau gastroenteritis. Hasil uji Salmonella sosis dapat dilihat pada gambar 6 berikut.

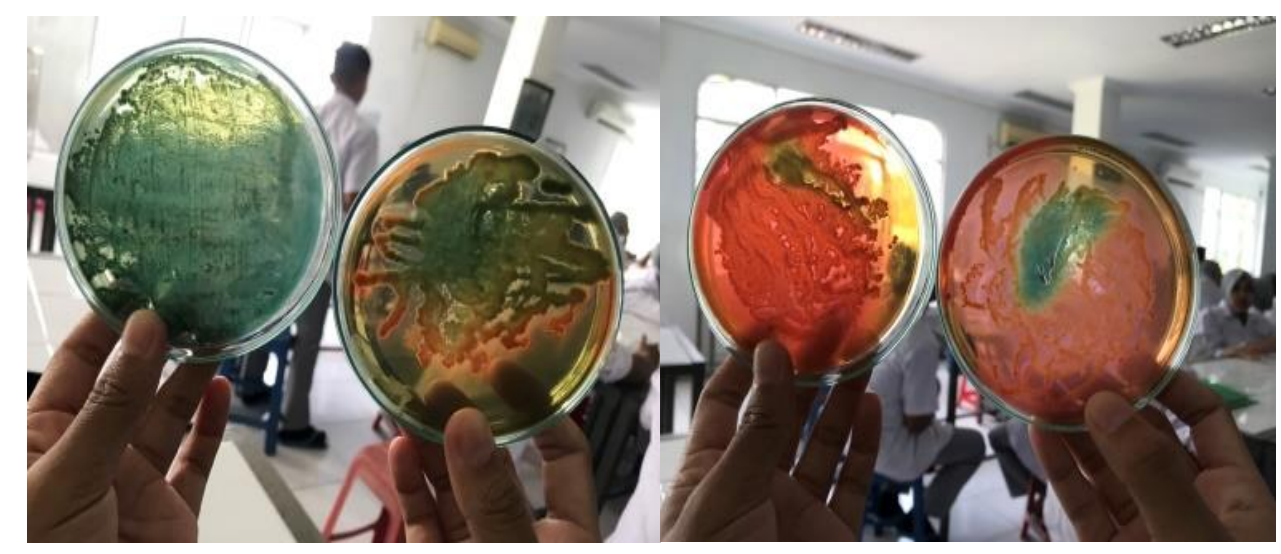

Gambar 6. Uji Salmonella sosis 


\section{SIMPULAN}

Hasil penelitian menunjukkan bahwa tepung rumput laut Gracilaria $s p$ berpengaruh terhadap karakteristik sosis ikan nila. Parameter hedonik menunjukkan perlakuan terbaik pada sosis ikan nila adalah penambahan tepung rumput laut Gracilaria sp sebesar $3 \%$. Penambahan tepung Gracilaria $s p$ akan menaikkan nilai kenampakan dan tekstur dan pengaruh terhadap sosis negatif mengandung bakteri E. coli, Coliform dan Salmonella

\section{DAFTAR PUSTAKA}

Astawan, M. 2004. "Pemanfaatan Karagenan (Eucheuma Cottonii) Untuk Meningkatkan Kadar lodium Dan Serat Pangan Pada Selai Dan Dodol." Jurnal Teknologi Dan Industri Pangan 15(1).

Badan Standardisasi Nasional. 2006. "Cara Uji Kimia Bagian 4: Penentuan Kadar Protein Dengan Metode Total Nitrogen Pada Produk Perikanan."

Badan Standardisasi Nasional. 2010. "Cara Uji Kimia - Bagian 1: Penentuan Kadar Abu Dan Abu Tak Larut Dalam Asam Pada Produk Perikanan."

Badan Standardisasi Nasional. 2013. "Sosis Ikan SNI 7755:2013."
Badan Standardisasi Nasional. 2015a. "Cara Uji Kimia Bagian 2 : Pengujian Kadar Air Pada Produk Perikanan."

Badan Standardisasi Nasional. 2015b. "Cara Uji Mikrobiologi Bagian 1: Penentuan Coliform Dan Escherichia Coli Pada Produk Perikanan."

Badan Standardisasi Nasional. 2015c. "Cara Uji Mikrobiologi Bagian 2: Penentuan Salmonella Pada Produk Perikanan."

Badan Standardisasi Nasional. 2015d. "Cara Uji Mikrobiologi Bagian 3: Penentuan Angka Lempeng Total (ALT) Pada Produk Perikanan."

Badan Standardisasi Nasional. 2015e. "Pedoman Pengujian Sensori Pada Produk Perikanan."

Badan Standardisasi Nasional. 2017. "Cara Uji Kimia Bagian 3: Penentuan Kadar Lemak Total Pada Produk Perikanan." Chapman, V. J., and D. J. Chapman. 1980. Seaweed and Their Uses. 3rd ed. London: Netherlands: Springer.

Estiasih, Teti, and Kgs Ahmadi. 2016. Teknologi Pengolahan Pangan. 2nd ed. Jakarta: Bumi Aksara. 
Fajriyanti. 2013. Modul Pengujian Organoleptik. Semarang.

Fardiaz, D. 2008. "Penuntun Praktikum Mikrobiologi Pangan."

Hasibuan, H. Malayu S. P. 2017. Organisasi Dan Motivasi Dasar Peningkatan Produktivitas. ed. mhs. Jakarta: Bumi Aksara.

Karim, Mutemainna, and Dian Nisa Fitri Aspari. 2015. "Pengaruh Penambahan Tepung Karagenan Terhadap Mutu Kekenyalan Bakso Ikan Gabus." Jurnal Balik Diwa 6(2):41-49.

Kementerian Pendidikan dan Kebudayaan Republik Indonesia. 2013. Pengolahan Diversifikasi Hasil Perikanan. Jakarta: Direktorat Pembinaan Sekolah Menengah Kejuruan.

De Man, J. M. 2010. Kimia Makanan. 2nd ed. Bandung: Institut Teknologi Bandung.

Princestasari, Lovi Dwi, and Leily Amalia. 2015. "Formulasi Rumput Laut Gracilaria $S p$. Dalam Pembuatan Bakso Daging Sapi Tinggi Serat Dan lodium." Jurnal Gizi Dan Pangan 10(3):185-96. doi: 10.25182/jgp.2015.10.3.

Pusat Pendidikan Kelautan dan Perikanan. 2015. Modul: Membuat Diversifikasi Produk
Perikanan. Jakarta: Badan Pengembangan SDM dan Pengembangan Masyarakat Kelautan dan Perikanan, Kementrian Kelautan dan Perikanan.

Ray, B., and A. Bhunia. 2007. Fundamental Food Microbiology. 4th Edition. United States of America.: CRC Press.

Sipahutar, Yuliati H., Husnul K. Ramli, M. G. E. Kristiani, D. H. G. Prabowo, M. R. Suryanto, and R. B. Pratama. 2019. "Chemical Composition of Whiteleg Shrimp (Litopenaeus Vannamei) Cultivated from Intensive Farming and Traditional Farming at Bulukumba Regency, South Sulawesi." in IOP Conference Series: Earth and Environmental Science. Vol. 399. IOP.

Sipahutar, Yuliati H, Arpan N. Siregar, MR Suryanto, Riza B. Pratama, Tina FC Panjaitan, and Pola ST Panjaitan. 2020. "Penambahan Tepung Rumput Laut (Gracilaria Sp ) Terhadap Karakteristik Mutu Ekado Ikan Nila ( Oreochromis Niloticus )." Pp. 244-49 in Prosiding Seminar Nasional Online Teknologi Pangan 
Pascapanen 2020. Bogor:

Balai Besar Penelitian dan

Pengembangan Pascapanen

Pertanian.

Sipahutar, Yuliati H., T. Taufiq, M. G.

E. Kristiani, D. H. G. Prabowo,

R. R. Ramadheka, M. R.

Suryanto, and R. B. Pratama. 2020. "The Effect of Gracilaria

Powder on the Characteristics

of Nemipterid Fish Sausage." IOP Conference Series: Earth and Environmental Science 404. doi: 10.1088/17551315/404/1/012033.

Sipahutar, Yuliati Hotmauli,

Muhamad Rahman, and Tina

FC Panjaitan. 2020. "Pengaruh

Penambahan Karagenan

Eucheuma Cottonii Terhadap

Karakteristik Ekado Ikan Nila."

Aurelia Journal 2(1):1. doi:

10.15578/aj.v2i1.8929.

Soekarto, T. S. 2008. Penilaian

Organoleptik: Untuk Industri

Pangan Dan Hasil Pertanian.

Jakarta: Bhrata Karya Aksara.

Suhartono, Angka L. 2000.

Bioteknologi Hasil Laut. Bogor:

Pusat Kajian Sumber Daya

Pesisir dan Lautan, IPB.

Sulistyaningrum, Tyas Wara. 2018.

"Optimalisasi Penambahan

Rumput Laut ( Eucheuma

Cottoni ) Sosis Ikan Lele (

Clarias Gariepinus )." Jurnal
IImu Hewani Tropika 7(2):51-

53.

Sulistyaningrum, Tyas Wara, and Elita. 2015. "Kajian Penambahan Karaginan Dari Rumput Laut (Eucheuma Cottoni) Terhadap Sifat-Sifat Organoleptik Sosis Ikan Lele (Clarias Gariepinus)." Jurnal IImu Hewani Tropika 4(2):6670.

Winarno, FG. 2014. Kimia Pangan Dan Gizi. Jakarta: Gramedia.

Wiraswanti, I., A. C. Erungan, and W. Zahiruddin. 2008. "Pemanfaatan Karagenan Dan Kitosan Dalam Pembuatan Bakso Ikan Kurisi (Nemipterus Nematophorus) Pada Penyimpanan Suhu Dingin Dan Beku." Buletin Teknologi Hasil Perikanan 11(1).

Yakhin, Lisa Amanda, Kristaliamulya Wijaya, and Joko Santoso. 2013. "Peningkatan Kualitas Gel Sosis Ikan Lele Dengan Penambahan Tepung Gracillaria Gigas." Jurnal Pengolahan Hasil Perikanan Indonesia 16(2).

Yaska, Qurotul IIma, Ni Made Yusa, and Ni Luh Yusasrini. 2017. "Pengaruh Rasio Tapioka Dengan Rumput Laut Gracilaria Sp. Terhadap Karakteristik Sosis Ikan Lemuru." Jurnal IImu Dan Teknologi Pangan (Itepa) 
$6(1)$. 